Contribution to Collaborative Innovation

\title{
Studies: Cases of SMES Moroccan Automotive Suppliers and their Client
}

\author{
Elharouni Fatine ${ }^{1}$, Benmoussa Rachid ${ }^{2}$, Ait Ouhmane Abdellah ${ }^{2}$ \\ ${ }^{1}$ Phd Student, Cadi Ayyad University, FSSM, Marrakesh, Morocco \\ ${ }^{2}$ Professors, Cadi Ayyad University, ENSA, Marrakesh, Morocco
}

\begin{abstract}
The aim of this work is to study how collaborative innovation succeeds between a large enterprise and SME relationship (ManufacturerEquipment) in automotive supply chain using case studies. Data were collected from semi-structured interviews with managers in nine firms. The main intention was to understand how these companies engaged collaborative innovation and what the factors were to make it successful. The study adopted a qualitative approach in the study of these factors. The results show the importance of the internal capacities of SMEs (management style, innovation capacities, knowledge management ...) in the success and valorization of such a project. The study provides important lessons on how these relationships can impact the way businesses operate and how they innovate.
\end{abstract}

Keywords- Automotive industry, Collaborative innovation, Knowledge management, Open innovation, SMEs.

\section{INTRODUCTION}

The Automotive Supply Chain is characterized by strong and rapid globalization, significant technology advances and great competition. This reality requires companies in the sector to look beyond their organizational boundaries to create exceptional value.

In this context, logistics and innovation become the mean that Constractors (large groups) use to acquire a competitive advantage. To achieve this, they need to integrate the various partners in their innovation and logistical optimization processes, and the automotive suppliers Rang1 as Direct Suppliers constitute the category concerned first and foremost among all the supply chain partners. the collaborative innovation - also referred to as open innovation - is an alternative solution to make saving budgetary.

\section{BACKGROUND}

The semantic sources of the word open innovation come from the "open source software" movement and it was in
2003 by Chesbrough. [9] Open innovation opposed to close one uses communities, external partners with a more open approach. Open innovation can be likened to collaborative innovation. Collaborative innovation is found especially in publications related to corporate networks for the development of a new product in project mode.

In the OECD sense [40], collaborative innovation must focus on the active participation of partners in the innovation development project. The definition excludes the simple outsourcing of $\mathrm{R} \& \mathrm{D}$ to put a single focus on innovation processes, outsourcing purely and simply work without active collaboration is not considered collaboration.

According to Miles [36] and Ketchen [30], «Collaborative innovation is the creation of innovations across firm (and perhaps industry) boundaries through the sharing of ideas, knowledge, expertise, and opportunities ».

We will consider open innovation as the paradigm of collaborative innovation. We see that Collaborative innovation is defined as the fact that an entity actively participates in innovation projects with other actors external to the company [26], in our case it is Suppliers with their Client.

\section{THE THEORETICAL FRAMEWORK FOR COLLABORATIVE INNOVATION}

The Many researcher like Yaseen [59] speaks about two orientations in collaborative innovation: the Relationship Orientation and Innovation Orientation. We propose to these two orientations a third one, the Knowledge Management Orientation which seems to us just as pertinent and which was strongly confirmed by our study. In the current researches it becomes clear that organizations can enhance their innovation capabilities by developing collaborations with a variety of partners. [7] The continuous and frequent exchange of information within and outside the organization (with customers and 
suppliers) can improve Collaborative Innovation and constitutes the Relationship Orientation.

Innovation Orientation has been increasingly recognized explicitly or tacitly in research on collaborative innovation [49]. Researchers call it a company's ability to innovate [60] [25], a propensity to innovate [13], a culture of innovation [15] [24], and shared learning integrated into practices and routines Organizational structures [23] [1]. The main of Innovation Orientation is to examine innovation capacities that capture perceptions and approaches across the organization to develop innovation [1] [ 48].

Also, many researchers have promoted the knowledge management and the culture of learning as an antecedent to innovation [25], [48] [23] [25] [1] [1]. Thus, the organization's propensity to create, use and disseminate knowledge enhances innovation capacity. [47] [1]. And the exchange of information, which includes the production, consumption and dissemination Which aims to strengthen the interaction between learning and innovation [47] [43].

\section{INTEREST AND PROBLEMS OF THE STUDY}

We analyze the collaborative innovation within the relationship of Moroccans SME s equipment suppliers Rangland their client, which is present in Morocco at Through its acquisition of the famous SOMACA factory in Casablanca.

How does collaborative innovation work between the Constructor and these SMEs? How does collaborative innovation succeed in breaking through the barriers of business and allowing the passage of knowledge? How is collaborative innovation spread and how it is perceived in the partner organization? And what are the best practices to recommend to these SMEs to assert themselves in such projects?

\section{METHODOLOGY}

The research consisted of a multiple qualitative case study, as little research was done on collaborative innovation in logistics. Appropriate research methods which produce valid interpretative knowledge require close contact with the field, as it is necessary to situate actors and their actions in their social context [52].

This research aims to understand the factors and examine relationships using content analysis and case comparison. Data were collected for nine case studies from semistructured interviews with 15 managers.

The main intention was to understand how these companies supported the collaborative innovation initiated by their Large Group client. The study adopted a qualitative approach in the study of these factors. Data were collected from participants in their workplace using semi-structured interviews.

This method allowed the input of data with details on the research problem and gave the researchers the flexibility to explore other issues raised by the participants. The use of multiple cases has also contributed to the reliability and generalizability of the results.[60][61]

A total of 15 interviews were conducted in nine organizations with senior and middle managers. During our meetings with the constructor's Teams, we selected the cases according to three main criteria: The first criteria relates to the direct relationship with the constructor so that they will be Rang1 equipment suppliers working in the automotive supplier sector Directly to the manufacture. The second is the geographical positioning, the study is limited to the factory area of the Casablanca and regions constructor. The third criteria is that they will only be Moroccan SMEs. The companies that meet these criteria are nine companies that all participated in the study by at least one representative. A summary of the activities of the nine companies is given in Table I.

\section{TABLE I. THE PRESENTATION OF THE CASE STUDY}

\begin{tabular}{|c|c|c|c|}
\hline \multirow[b]{2}{*}{$\begin{array}{c}\text { Th } \\
\text { e } \\
\text { fir } \\
\text { ms }\end{array}$} & \multicolumn{3}{|c|}{ Information } \\
\hline & The activity & $\begin{array}{c}\text { Numbe } \\
\text { r of } \\
\text { employ } \\
\text { ees }\end{array}$ & $\begin{array}{c}\text { The } \\
\text { product }\end{array}$ \\
\hline E1 & $\begin{array}{l}\text { Plastics processing: } \\
\text { bumpers, trim parts and } \\
\text { lining }\end{array}$ & $\begin{array}{l}\text { More } \\
\text { than } \\
100\end{array}$ & $\begin{array}{l}\text { Plastic } \\
\text { Compone } \\
\text { nts }\end{array}$ \\
\hline E2 & $\begin{array}{l}\text { Glass manufacturing For } \\
\text { building and industrial } \\
\text { vehicles }\end{array}$ & $\begin{array}{l}\text { More } \\
\text { than } \\
100\end{array}$ & Glass \\
\hline E3 & $\begin{array}{l}\text { Manufacturing and } \\
\text { Foundry Machining of } \\
\text { Foundry Component }\end{array}$ & $\begin{array}{l}\text { More } \\
\text { than } \\
100\end{array}$ & $\begin{array}{l}\text { Foundry } \\
\text { Compone } \\
\text { nt }\end{array}$ \\
\hline E4 & $\begin{array}{l}\text { Manufacture of car seats, } \\
\text { seating covers and self- } \\
\text { extinguishing cold mold } \\
\text { foam, covers for } \\
\text { automobiles, various } \\
\text { accessories for } \\
\text { automobiles, synthetic } \\
\text { foam for car seats, } \\
\text { cataphoresis painting for } \\
\text { metal parts }\end{array}$ & $\begin{array}{l}\text { Betwee } \\
\text { n } 50 \\
\text { and } 99\end{array}$ & $\begin{array}{l}\text { Seats and } \\
\text { side } \\
\text { dishes(fill } \\
\text { ings) } \\
\text { Parchoc, } \\
\text {.. }\end{array}$ \\
\hline E5 & $\begin{array}{l}\text { Manufacturing of seats for } \\
\text { automobiles, coaches, } \\
\text { trucks and others. }\end{array}$ & $\begin{array}{l}\text { Betwee } \\
\text { n } 50 \\
\text { and } 99\end{array}$ & $\begin{array}{l}\text { Seats and } \\
\text { side } \\
\text { dishes }\end{array}$ \\
\hline E6 & $\begin{array}{l}\text { Manufacturing of cables of } \\
\text { remote control for the car }\end{array}$ & $\begin{array}{l}\text { More } \\
\text { than }\end{array}$ & $\begin{array}{l}\text { Filters } \\
\text { and }\end{array}$ \\
\hline
\end{tabular}

Page | 266 


\begin{tabular}{|c|c|c|c|}
\hline \multirow[b]{2}{*}{$\begin{array}{l}\text { Th } \\
\text { e } \\
\text { fir } \\
\text { ms }\end{array}$} & \multicolumn{3}{|c|}{ Information } \\
\hline & The activity & $\begin{array}{c}\text { Numbe } \\
\text { r of } \\
\text { employ } \\
\text { ees }\end{array}$ & $\begin{array}{c}\text { The } \\
\text { product }\end{array}$ \\
\hline & industry & 100 & $\begin{array}{l}\text { cables of } \\
\text { remote } \\
\text { control }\end{array}$ \\
\hline E7 & $\begin{array}{l}\text { Manufacturing of the } \\
\text { Filters of the air, the oil } \\
\text { and the fuel for the engines } \\
\text { of passenger cars and } \\
\text { industrial applications }\end{array}$ & $\begin{array}{l}\text { More } \\
\text { than } \\
100\end{array}$ & $\begin{array}{l}\text { Filters } \\
\text { and } \\
\text { cables of } \\
\text { remote } \\
\text { control }\end{array}$ \\
\hline E8 & $\begin{array}{l}\text { Transformer of wire for } \\
\text { the car industry, the } \\
\text { display stands in wire, } \\
\text { epoxy paint(painting) }\end{array}$ & $\begin{array}{l}\text { More } \\
\text { than } \\
100\end{array}$ & $\begin{array}{l}\text { Metal } \\
\text { Wires }\end{array}$ \\
\hline E9 & $\begin{array}{l}\text { Manufacturing Exhaust } \\
\text { pipes and } \\
\text { transformation(processing) } \\
\text { of metals (collision, } \\
\text { folding) }\end{array}$ & $\begin{array}{l}\text { More } \\
\text { than } \\
100\end{array}$ & $\begin{array}{l}\text { Exhaust } \\
\text { pipes and } \\
\text { transform } \\
\text { ation of } \\
\text { metals }\end{array}$ \\
\hline
\end{tabular}

The main intention was to understand how a notion such as collaborative innovation is engaged in the automotive sector between these Moroccan SMEs and a large Group.

\section{RESULTS AND DISCUSSIONS}

The results of this study show that there was collaborative innovation in the nine companies providing SOMACA, but elementary and closed between the manufacturer and one supplier at a time.

Examining the reasons for the launch of collaborative innovation shows that the search for suppliers capable of offering more competitive. The Constructor plays both the role of Controller and / or Accompanist in order to upgrade them.

Other analyzes were also conducted to show how the various initiatives and strategies improved collaborative innovation for each case. This is summarized in Table II.

TABLE II. THE RESULTS ARISING FROM THE ANALYSIS OF THE SITUATION OF COLLABORATIVE INNOVATION BETWEEN THE 9 SMES AND THE SOMACA

\begin{tabular}{|c|c|c|}
\hline $\begin{array}{c}\text { Specificati } \\
\text { ons }\end{array}$ & Explanations & $\begin{array}{c}\text { Représentat } \\
\text { ivité chez } \\
\text { les cas } \\
\text { étudiés } \\
\text { PME }\end{array}$ \\
\hline $\begin{array}{l}\text { The type of } \\
\text { collaborativ } \\
\text { e }\end{array}$ & $\begin{array}{l}\text { Closed system: The } \\
\text { customer (builder) with } \\
\text { each supplier (SME) }\end{array}$ & $\begin{array}{l}\text { All Business } \\
\text { E1 E2 E3 E4 } \\
\text { E5 E6 E8 }\end{array}$ \\
\hline
\end{tabular}

\begin{tabular}{|c|c|c|}
\hline $\begin{array}{l}\text { Specificati } \\
\text { ons }\end{array}$ & Explanations & $\begin{array}{c}\text { Représentat } \\
\text { ivité chez } \\
\text { les cas } \\
\text { étudiés } \\
\text { PME }\end{array}$ \\
\hline $\begin{array}{l}\text { innovation } \\
\text { system }\end{array}$ & $\begin{array}{l}\text { alone } \\
\text { Low SME opening rate }\end{array}$ & \\
\hline $\begin{array}{l}\text { The types } \\
\text { of } \\
\text { innovation } \\
\text { that are the } \\
\text { subject of } \\
\text { collaborativ } \\
\text { e } \\
\text { innovation }\end{array}$ & $\begin{array}{l}\text { Non-contractual } \\
\text { innovation } \\
\text { Organizational innovation } \\
\text { Process innovation } \\
\text { Product innovation }\end{array}$ & $\begin{array}{l}\text { All Business } \\
\text { E1 E2 E3 E5 } \\
\text { E6 E7 E8 E9 } \\
\text { E1 E2 E4 E5 } \\
\text { E6 E7 E8 E9 } \\
\text { E1 E4 E5 E7 }\end{array}$ \\
\hline $\begin{array}{l}\text { Involvemen } \\
\mathrm{t} \text { in } \\
\text { collaborativ } \\
\mathrm{e} \\
\text { innovation }\end{array}$ & $\begin{array}{l}\text { Lack of involvement of } \\
\text { SMEs in the idea-finding } \\
\text { phase } \\
\text { Involvement of SMEs in } \\
\text { the implementation }\end{array}$ & $\begin{array}{l}\text { All Business } \\
\text { All Business }\end{array}$ \\
\hline $\begin{array}{l}\text { The } \\
\text { frequency } \\
\text { of } \\
\text { relationship }\end{array}$ & $\begin{array}{l}\text { high frequency of the } \\
\text { relationship } \\
\text { Geographic proximity } \\
\text { Exchange of direct } \\
\text { information (Meetings, } \\
\text { Reports and Audits) }\end{array}$ & $\begin{array}{l}\text { All Business } \\
\text { E4 E5 } \\
\text { All Business }\end{array}$ \\
\hline $\begin{array}{l}\text { Quality of } \\
\text { the } \\
\text { relationship }\end{array}$ & $\begin{array}{l}\text { SMEs' dissatisfaction with } \\
\text { the quality of the } \\
\text { collaborative relationship } \\
\text { Good Communication and } \\
\text { Trust } \\
\text { Expectations not met } \\
\text { (loyalty, financial aid ...) } \\
\text { and } \\
\text { Relationship governance } \\
\text { (verification of } \\
\text { compliance with mutual } \\
\text { commitments) }\end{array}$ & $\begin{array}{l}\text { All Business } \\
\text { All Business } \\
\text { E2, E3, E4, } \\
\text { E6, E7, E8, } \\
\text { E9. } \\
\text { E2, E3, E4, } \\
\text { E6, E7, E8, } \\
\text { E9. }\end{array}$ \\
\hline $\begin{array}{l}\text { Internal } \\
\text { SME } \\
\text { Manageme } \\
\text { nt } \\
\text { Capabilities }\end{array}$ & $\begin{array}{l}\text { The executive's } \\
\text { management style } \\
\text { The management } \\
\text { structure of the } \\
\text { collaborative innovation }\end{array}$ & $\begin{array}{l}\text { E2, E3, E5, } \\
\text { E6, E7, E8, } \\
\text { E9. } \\
\text { E2, E3, E4, } \\
\text { E5, E6, E7, }\end{array}$ \\
\hline
\end{tabular}




\begin{tabular}{|c|c|c|}
\hline $\begin{array}{l}\text { Specificati } \\
\text { ons }\end{array}$ & Explanations & $\begin{array}{c}\text { Représentat } \\
\text { ivité chez } \\
\text { les cas } \\
\text { étudiés } \\
\text { PME }\end{array}$ \\
\hline $\begin{array}{l}\text { to Succeed } \\
\text { in } \\
\text { Collaborati } \\
\text { ve } \\
\text { Innovation }\end{array}$ & $\begin{array}{l}\text { project (the profile of the } \\
\text { project team on both } \\
\text { sides, the internal project } \\
\text { manager) }\end{array}$ & E8, E9. \\
\hline $\begin{array}{l}\text { Internal } \\
\text { innovation } \\
\text { capacities } \\
\text { of SMEs to } \\
\text { succeed in } \\
\text { collaborativ } \\
\text { e } \\
\text { innovation }\end{array}$ & $\begin{array}{l}\text { Dynamic capabilities } \\
\text { (ability to take a present } \\
\text { situation and reshape it to } \\
\text { its advantage) } \\
\text { Absorption capacity } \\
\text { (capacity to recognize and } \\
\text { use information for } \\
\text { commercial purposes) }\end{array}$ & $\begin{array}{l}\text { E2, E3, E4, } \\
\text { E5, E6, E7, } \\
\text { E8, E9. } \\
\text { E1, E2, E4, } \\
\text { E5, E6, E7, } \\
\text { E8, E9. } \\
\text { E2, E3, E4, } \\
\text { E5, E6, E7, } \\
\text { E8, E9. }\end{array}$ \\
\hline & $\begin{array}{l}\text { Capacity of ownership } \\
\text { (the ability to incorporate } \\
\text { advances into everyday } \\
\text { life) }\end{array}$ & \\
\hline $\begin{array}{l}\text { Knowledge } \\
\text { managemen } \\
\text { t of SMEs }\end{array}$ & $\begin{array}{l}\text { The innovation capacity } \\
\text { of an SME largely } \\
\text { depends on its ability to } \\
\text { learn } \\
\text { Innovation capabilities are } \\
\text { core capabilities for } \\
\text { Knowledge Management } \\
\text { The frequent collaborative } \\
\text { relationship offered data } \\
\text { for Knowledge } \\
\text { Management }\end{array}$ & $\begin{array}{l}\text { All Business } \\
\text { Except E1 } \\
\text { and E3 } \\
\text { All Business } \\
\text { Except E1 }\end{array}$ \\
\hline
\end{tabular}

We found that the relational aspect in their collaborative innovation projects is based more on the mechanisms of exchange and governance of the relationship.

The interviews confirm the importance of explicit intention and the predisposition of the constructor to share his knowledge and information.

At several stages of the interviews the component leader profile appeared in the remarks as internal factors very influential in terms of:

- Personal qualification and Values

- Strategic Capabilities of the Leader
- Quality of social links with its environment

Moreover, the capabilities and the predisposition of the supplier also determine the success of collaborative innovation, such as dynamic capacities

The role of the two organizations to involve and empower the teams in interface to encourage the setting up of a context conducive to the sharing of knowledge between the Constructor and its supplier. Through the setting up of an internal project team whose interest will be firstly to enable the company to have a vision and an understanding as complete as possible of the innovation initiated.

it emerged from our analysis that the major challenge in the success of collaborative innovation is the knowledge management and the internal capacities of the SME with which the project is made.

\section{CONCLUSION AND PERSPECTIVES}

In this study, the client is committed to continuously improving the supplier and sharing knowledge by exchanging relevant information and working together to initiate innovations and solve problems. The executive interviewed reported that the significant performance are observed in terms of: improved customer service, improved productivity, reduced costs, reduced cycle times and improved quality. It can be concluded that collaborative innovation improves the position of a company and can lead to a competitive advantage as well as innovative results.

The literature supports the results that emerge from this study. The collaborative innovation capabilities and initiatives discussed in the document provide the decision-maker with inspiration for future decisions and to encourage the development of innovative relationships that interact with different actors in the environment. It also shows the importance of collaborative innovation in the formation of knowledge in the organization and access to new skills and technological means that may be above the means of SMEs.

\section{REFERENCES}

[1] Baker, W. \&. (2002). Market orientation, learning orientation and product innovation: delving into the organization's black box. Journal of MarketFocused Management.

[2] Bessette, K. (2011). L'innovation ouverte : Revue de littérature.

[3] Blomqvist, K. \&. (2006). Collaboration capability: a focal concept in knowledge creation and collaborative innovation in networks'. International Journal of Management Concepts and Philosophy .

[4] Bogers, M. (2012). Knowledge Sharing in Open Innovation:Open Innovation An Overview of 
Theoretical Perspectives on Collaborative Innovation.

[5] Branzei, O. \&. (2006). Strategic pathways to product innovation capabilities in SMEs. Journal of Business Venturing .

[6] Cardon, D. (2006). Colloque Innovations, Usages, Réseaux. La trajectoire des innovations ascendants: inventivité, coproduction et collectives sur Internet.

[7] Chaze-Magnan, L. B. (2013). Pour une théorie des Pratiques Inter-organisationnelles Innovantes (P2I) : Proposition d'un modèle conceptuel. XXII Conférence Internationale de Management Stratégique.

[8] Chen, I. \&. (2004). Towards a theory of supply chain management: the constructs and measurements. Journal of Operations Management .

[9] Chesbrough, H. (2003). Open innovation. The new imperative for creating and profiting from technology. Boston : Harvard Business School Press.

[10] Chiva, R, Alegre, J \& Lapiedra. (2007). Measuring organisational learning capability among the workforce. International Journal of Manpower .

[11]Chiva, R. A. (2007). Measuring organisational learning capability among the workforce. International Journal of Manpower .

[12] Comeau, Y. (1994). L'analyse des données qualitatives. Cahiers du CRISES (Collectif de Recherche sur les Innovations Sociales dans les Entreprises et les Syndicats), Cahier n94-02.

[13] Damanpour. (1991). Organizational innovation: a meta-analysis of effects of determinants and moderators. The Academy of Management Journal .

[14]Day. (1994). The capabilities of market-driven organizations. Journal of Marketing, .

[15]Dobni. (2008). Measuring innovation culture in organizations: the development of a generalized innovation culture construct using exploratory factor analysis. European Journal of Innovation Management .

[16]Dodgson, M. (1993). Technological collaboration in industry: strategy, policy and internationalization in innovation. . London: Routledge.

[17] Drouin, N. B. (2012). Collaborative capability to build innovative projects. XXIII ISPIM Conference-- Action for Innovation: Innovating from Experience.

[18] Drucker. (2007a). Innovation and entrepreneurship: practice and principles.

[19] Dyer, J. \&. (1998). The relational view: cooperative strategy and sources of interorganizational competitive advantage. The Academy of Management Review .
[20]Eisenhardt, K. \&. (2000). Dynamic capabilities: what are they? Strategic Management Journal .

[21]Eisenhardt, K. (1989). Building Theories from case study research. Academy of Management Review , 532-550.

[22]Faems, D. V. (2005). Inter-organizational collaboration and innovation:Toward a portfolio approach.

[23]Huber. (1991). Organizational learning: the contributing processes and the literatures. Organization Science .

[24]Hult, G. H. (2004). Innovativeness: Its antecedents and impact on business performance. Industrial Marketing Management .

[25]Hurley, R. \&. (1998). Innovation, market orientation, and organizational learning: an integration and empirical examination. Journal of Marketing .

[26] INPI. (2012). Innovation collaborative et propriété intellectuelle Quelques bonnes pratiques. Paris : Institut national de la propriété industrielle .

[27] Johnsen, T. F. (2001). Managing networks of supplier and customer relationships for technological innovation: initial case study findings,. in: IMP-Conference in Oslo,Norway. Oslo,Norway.

[28] Kahn, K. \&. (1996). Logistics and interdepartmental integration. International Journal of Physical Distribution \& Logistics Management .

[29]Kale, P. D. (2002). Alliance Capability, Stock Market Response, and Long-Term Alliance Success: The Role of the Alliance Function. Strategic Management Journal .

[30] Ketchen, D. J. (2007). Strategic entrepreneurship, collaborative innovation, and wealth creation . the Strategic Entrepreneurship Journal Launch Conference Chicago .

[31] Kühne, B. G. (2013). The influence of relationship quality on the innovation capacity in traditional food chains. Supply Chain Management: An International Journal .

[32]Lazzaroti, V. e. (2009). Different Modes of Open Innovation : ATheoretical Framework and an Empirical Study. International Journal of Innovation Management .

[33]LOIC, R. (2015). loic-richard.com/blog/mesarticles/linnovation-collaborative-et-developpementinternational.

[34] Manu, F. \&. (1996). Innovation, marketing strategy, environment, and performance. Journal of Business Research .

[35] Méda, P. (2012 ). Tour d 'horizon de 1 'innovation ouverte et participati ve. 
[36] Miles, R. M. (2005). Collaborative entrepreneurship: How communities of networked firms use continuous innovation to create economic wealth. Stanford,: Stanford University Press.

[37] Miles, R. S. (1978). Organizational strategy, structure, and process. The Academy of Management Review.

[38] Morgan, R. \&. (1994). The commitment-trust theory of relationship marketing. Journal of Marketing .

[39] Mukamurera, J. L. (2006). Des avancées en analysequalitative : pour une transparence et une systématisation des pratiques »,. Revue de Recherche Qualitatives, Vol. 26, $n^{\circ} 1$, pp. 110-138.

[40] OCDE. (2005). Oslo Manual: Guidelines for Collecting and Interpreting Innovation Data. 3rd Edition, Organisation de Coopération et de Développement Economiques (OCDE).

[41] Pisano. (2008). What kind of innovation IS ri ght for you. Harvard Business Review , 86(12), 79-86 .

[42] Poppo, L. \&. (2002). Do formal contracts and relational governance function as substitutes or complements? Strategic Management Journal .

[43] Powell, W. K.-D. (1996). Interorganizational collaboration and the locus of innovation: Networks of learning in biotechnology. Administrative Science Quarterly.

[44]Ring, P. \&. (1994). Developmental processes of cooperative interorganizational relationships. The Academy of Management Review .

[45] Rothaermel, F. (2003). Honeymoons and liabilities: the relationship between age and performance in research and development alliances. Journal of Product Innovation Management, 20 . 468-485.

[46] Schreiner, M. \&. (2004). Integrating perspectives: a multidimenesional construct of collaborative capability. Complex collaboration : building the capabilities for working across boundaries .

[47] Senge. (1990). The leader's new work: building learning organizations. Sloan Management Review .

[48] Siguaw, J. S. (2006). Coceptualizing innovation orientation: a framework for study and integration of innovation research. Journal of Product Innovation Management .

[49] Siguaw, JA, Simpson, PM \& Enz. (2006). Coceptualizing innovation orientation: a framework for study and integration of innovation research. Journal of Product Innovation Management .

[50] Sivadas, E. \&. (2000). An examination of organizational factors influencing new product success in internal and alliance-based processes. Journal of Marketing .
[51] Soosay, C. A. (2008). Supply chain collaboration: capabilities for continuous innovation. Supply Chain Management: An International Journal , 160-169.

[52] Stoyanov, S. (2008). Linking value creation and value capture to open innovation. . Mémoire de maîtrise, Belgique: Université Hasselt.

[53] Thietart, R. A. (2007). Méthodes de recherche en management. Paris: DUNOD, 3ème édition.

[54]Tuominen, M. R. (2004). How does adaptability drive firm innovativeness?'. Journal of Business Research.

[55] Ulbrich, S. T. (2011). 'How teams in networked organisations develop collaborative capability: processes, critical incidents and success factors.

[56] Wagner, M. S. (2009). Supplier traits for better customer firm innovation performance. Industrial Marketing Management .

[57] Weick, K. S. (2005). Organizing and the process of sensemaking. Organization Science .

[58] Wernerfelt, B. (1984). The resource-based view of the firm. Strategic Management Journal .

[59] Yaseen, A., \& Somogyi, S. (2014). Developing collaborative capability for innovation in food industry. 2ndInternational Conference on Marketing, Colombo, Sri Lanka, 25-26th February.

[60] Yin, R. (1994) Case study research: design and methods (2 éd.). London: Sage.

[61] Yin, R. (2003) Application of Case study. London: Sage.

[62]Zien, K. \&. (1997). From Experience Dreams to Market: Crafting a Culture of Innovation. Journal of Product Innovation Management . 